\title{
A domain of the actin binding protein Abp140 is the yeast methyltransferase responsible for 3-methylcytidine modification in the tRNA anti-codon loop
}

\author{
SONIA D'SILVA, STEFFEN J. HAIDER, and ERIC M. PHIZICKY \\ Department of Biochemistry and Biophysics and Center for RNA Biology, University of Rochester School of Medicine, Rochester, New York \\ 14642, USA
}

\begin{abstract}
The 3-methylcytidine $\left(\mathrm{m}^{3} \mathrm{C}\right)$ modification is widely found in eukaryotic species of tRNA ${ }^{\text {Ser }}$, $t_{R N A}{ }^{\text {Thr }}$, and tRNA ${ }^{\text {Arg }}$; at residue 32 in the anti-codon loop; and at residue 2 in the variable stem of tRNA ${ }^{\text {Ser }}$. Little is known about the function of this modification or about the specificity of the corresponding methyltransferase, since the gene has not been identified. We have used a primer extension assay to screen a battery of methyltransferase candidate knockout strains in the yeast Saccharomyces cerevisiae, and find that tRNA ${ }^{\text {Thr(IGU) }}$ from abp140- $\Delta$ strains lacks $\mathrm{m}^{3} \mathrm{C}$. Curiously, Abp140p is composed of a poorly conserved N-terminal ORF fused by a programed +1 frameshift in budding yeasts to a C-terminal ORF containing an $S$-adenosylmethionine (SAM) domain that is highly conserved among eukaryotes. We show that $A B P 140$ is required for $\mathrm{m}^{3} \mathrm{C}$ modification of substrate tRNAs, since primer extension is similarly affected for all tRNA species expected to have $\mathrm{m}^{3} \mathrm{C}$ and since quantitative analysis shows explicitly

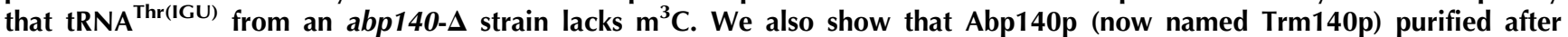
expression in yeast or Escherichia coli has $m^{3} \mathrm{C}$ methyltransferase activity, which is specific for tRNA ${ }^{\text {Thr(IGU) }}$ and not tRNA ${ }^{\text {Phe }}$ and occurs specifically at $C_{32}$. We suggest that the $C$-terminal ORF of Trm140p is necessary and sufficient for activity in vivo and in vitro, based on analysis of constructs deleted for most or all of the $\mathrm{N}$-terminal ORF. We also suggest that $\mathrm{m}^{3} \mathrm{C}$ has a role in

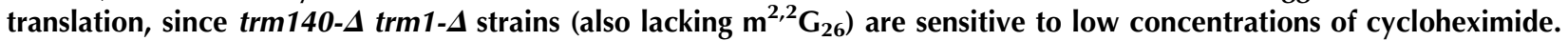

Keywords: 3-methycytidine; S. cerevisiae; TRM140; ABP140; tRNA; frameshift

\section{INTRODUCTION}

tRNA molecules are widely modified in nature, with a total of 92 chemically distinct tRNA modifications identified in different organisms and entered in the RNA modification database (http://rna-mdb.cas.albany.edu/RNAmods/). In the yeast Saccharomyces cerevisiae, 25 different tRNA modifications are found, at 36 different positions, among the 34 sequenced tRNA species (Sprinzl and Vassilenko 2005), with an average of 12.6 modifications per tRNA species (Phizicky and Hopper 2010). These modifications display two broadly defined roles. First, a number of modifications in and around the anti-codon loop play distinct roles in translation, affecting charging of the tRNA with the correct amino acid,

Reprint requests to: Eric M. Phizicky, Department of Biochemistry and Biophysics and Center for RNA Biology, University of Rochester School of Medicine, 601 Elmwood Avenue, Box 712, Rochester, NY 14642, USA; e-mail: eric_phizicky@urmc.rochester.edu; fax: (585) 271-2683.

Article published online ahead of print. Article and publication date are at http://www.rnajournal.org/cgi/doi/10.1261/rna.2652611. reading frame maintenance, or the efficiency and/or accuracy of translation (Phizicky and Hopper 2010). Second, a number of modifications in the main body of the tRNA remote from the anti-codon have a role in the biogenesis or maintenance of tRNA, and mutations in these modifications lead to turnover of pre-tRNA or mature tRNA by different quality control pathways (Kadaba et al. 2004; Chernyakov et al. 2008). Over the past decade, the enzymes and their cognate genes responsible for most of these modifications have been defined (Phizicky and Hopper 2010).

One of the remaining unidentified yeast genes encoding modification enzymes is the methyltransferase responsible for formation of 3-methylcytidine $\left(\mathrm{m}^{3} \mathrm{C}\right)$. The $\mathrm{m}^{3} \mathrm{C}$ modification is widely found in eukaryotic tRNA ${ }^{\mathrm{Ser}}, \mathrm{tRNA}^{\mathrm{Thr}}$, and RNA $^{\text {Arg }}$ tRNA species at residue 32 of the anti-codon loop (Sprinzl and Vassilenko 2005). $\mathrm{m}^{3} \mathrm{C}_{32}$ is found in all four characterized cytoplasmic tRNA ${ }^{\mathrm{Thr}}$ species from animals or fungi, in bovine liver mitochondrial tRNA ${ }^{\mathrm{Th}}$ (UGU), in all but one of the 15 characterized cytoplasmic tRNA ${ }^{\text {Ser }}$ species from plants and animals, in four of the five characterized 
fungal cytoplasmic tRNA ${ }^{\text {Ser }}$ species with an encoded $\mathrm{C}_{32}$ residue, and in bovine mitochondrial tRNA ${ }^{\mathrm{Ser}(\mathrm{UGA})}$, as well as in two of the five characterized tRNA ${ }^{\mathrm{Arg}}$ species from animals. Curiously, $\mathrm{m}^{3} \mathrm{C}$ is also found at residue $\mathrm{e} 2$ of the variable loop of the seven cytoplasmic tRNA ${ }^{\text {Ser }}$ species from animals. In the yeast $S$. cerevisiae, $\mathrm{m}^{3} \mathrm{C}$ is found at $\mathrm{C}_{32}$ of tRNA $^{\text {Thr(IGU) }}$ tRNA $^{\text {Ser(UGA) }}$, and tRNA ${ }^{\text {Ser(CGA) }}$ (Weissenbach et al. 1977; Sprinzl and Vassilenko 2005; Dunin-Horkawicz et al. 2006).

It seems likely that the $\mathrm{m}^{3} \mathrm{C}_{32}$ modification would have an important role in the cell, since residue 32 of the anti-codon loop interacts with residue 38 to maintain the structure of the anti-codon loop (Auffinger and Westhof 1999, 2001), an interaction that is known to be important for decoding accuracy (Olejniczak et al. 2005; Olejniczak and Uhlenbeck 2006; Ledoux et al. 2009). However, since its discovery some $47 \mathrm{yr}$ ago (Hall 1963), little has been discovered about the biology and function of $\mathrm{m}^{3} \mathrm{C}$ or about the rules that govern the specificity of this modification in vivo.

To begin to define the biochemical basis of $\mathrm{m}^{3} \mathrm{C}$ modification in the cell and the roles of the modification, we have carried out a systematic screen to identify the gene encoding the $\mathrm{m}^{3} \mathrm{C}$ methyltransferase responsible for this modification. To our surprise, we find that the methyltransferase is the actin-binding protein Abp140p (Asakura et al. 1998), which is necessary and sufficient for the $\mathrm{m}^{3} \mathrm{C}$ modification (now renamed TRM140 to indicate its tRNA modification activity). It is intriguing that $A B P 140$ is translated by a programed frameshift (Farabaugh et al. 2006b), which fuses an upstream ORF that is variable among different species and implicated in organization of the actin cytoskeleton in the cell (Asakura et al. 1998), with a downstream ORF that, like $\mathrm{m}^{3} \mathrm{C}$, is conserved among eukaryotes. We find that this downstream ORF, which has a SAM binding domain (Katz et al. 2003), is necessary and sufficient for $\mathrm{m}^{3} \mathrm{C}$ methyltransferase activity in vitro and in vivo. We also find that although $a b p 140-\Delta$ strains have no obvious growth phenotype, abp140- $\Delta$ trm1- $\Delta$ cells, which are missing both $\mathrm{m}^{3} \mathrm{C}$ and $\mathrm{m}^{2,2} \mathrm{G}$, have a distinct, but modest, growth defect in the presence of a translation inhibitor, suggesting a role for $\mathrm{m}^{3} \mathrm{C}$ in translation.

\section{RESULTS}

\section{The yeast $A B P 140$ gene is required for formation of $\mathrm{m}^{3} \mathrm{C}$}

To determine the gene responsible for $\mathrm{m}^{3} \mathrm{C}$ modification of tRNA in yeast, we first developed a sensitive primer extension assay to detect the modification, using yeast tRNA ${ }^{\text {Thr(IGU), }}$ which is known to contain $\mathrm{m}^{3} \mathrm{C}_{32}$ (Weissenbach et al. 1977). We purified tRNA ${ }^{\text {Thr(IGU) }}$ from wild-type yeast cells, annealed a labeled primer designed to pair with the tRNA from residue 55 in the $\mathrm{T}$-loop through residue 35 in the anticodon loop (Fig. 1A), and extended the primer with reverse transcriptase. Extension resulted in a product that terminated at residue 33 because of the presence of the $\mathrm{m}^{3} \mathrm{C}$ modification at $\mathrm{C}_{32}$ (Fig. $1 \mathrm{~B}$, lanes $\mathrm{a}-\mathrm{c}$ ). In contrast, primer extension of the same tRNA after treatment with the bacterial demethylase $\mathrm{AlkB}$ to eliminate the $\mathrm{m}^{3} \mathrm{C}$ residue (Aas et al. 2003), as well as the $\mathrm{m}^{2,2} \mathrm{G}$ modification, resulted in a fully extended primer extension product (Fig. 1B, lanes $\mathrm{d}, \mathrm{e})$. Thus, the presence and absence of the $\mathrm{m}^{3} \mathrm{C}$ residue could be scored based on the length of the primer extension product.

To identify the gene responsible for $\mathrm{m}^{3} \mathrm{C}$ modification of tRNA $^{\text {Thr(IGU) }}$, we employed the primer extension assay to
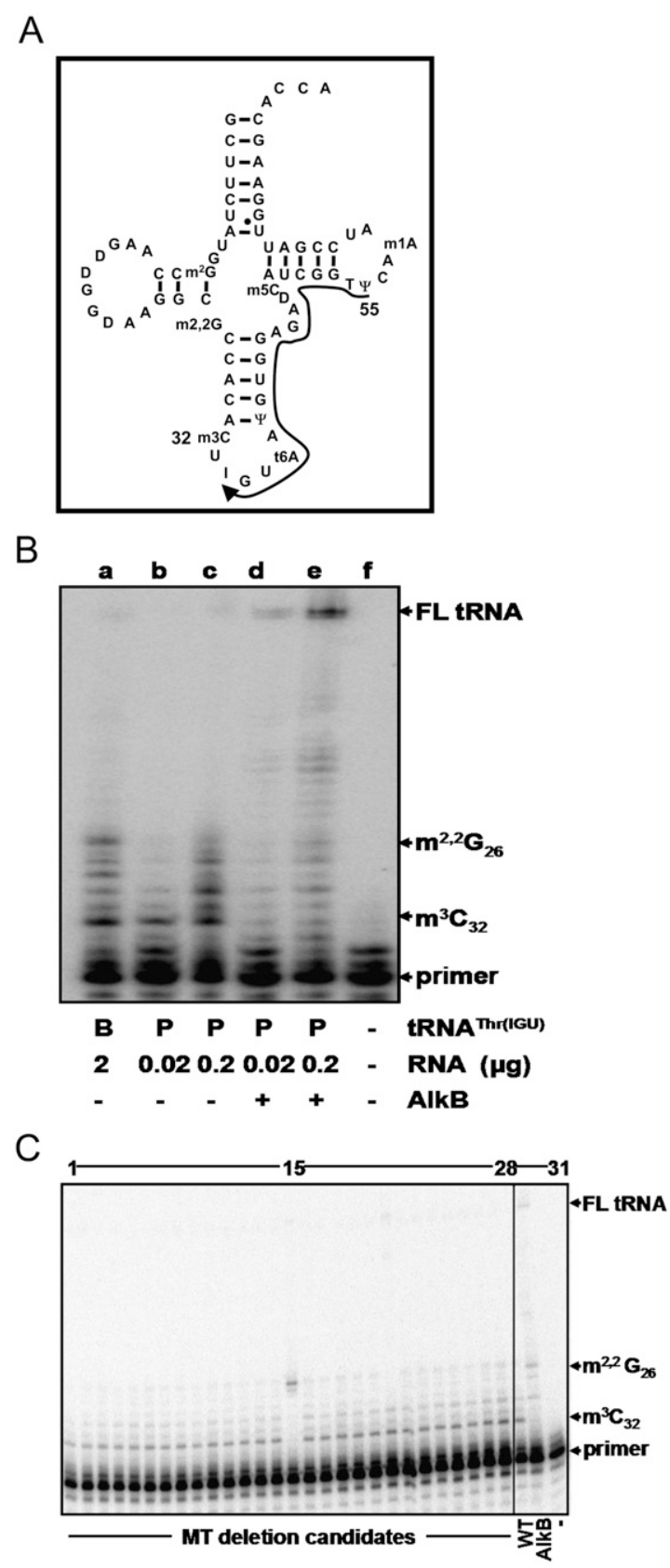

FIGURE 1. (Legend on next page) 
screen candidates from the yeast haploid deletion collection. Based on a text search for methyltransferases in SGD (http://www.yeastgenome.org/cgi-bin/search/textSearch.pl? query $=$ methyltransferase\&type $=$ headline), a search of Gcd14like domains in SGD (http://www.yeastgenome.org/cgi-bin/ protein/domainPage.pl?dbid=S000003661), and a methyltransferase search in the Modomics database (DuninHorkawicz et al. 2006), we came up with a list of 86 strains with deletions of nonessential genes that encode known methyltransferases, uncharacterized ORFs with similarity to known methyltransferases, or known partners of methyltransferase proteins (Supplemental Table S1). RNA prepared from 77 of these strains was analyzed, yielding one candidate with an extended primer extension product (Fig. 1C). This strain has a deletion of $A B P 140$, which encodes an actin binding protein that co-localizes with actin cables and cortical actin patches (Asakura et al. 1998) and which is synthesized as a programed frameshift of ORF YOR239W with YOR240W (Farabaugh et al. 2006b).

To confirm that $A B P 140$ is responsible for the primer extension block indicative of $\mathrm{m}^{3} \mathrm{C}$ modification of $\mathrm{tRNA}{ }^{\mathrm{Thr}(\mathrm{IGU})}$, we reconstructed and tested abp140 deletion strains. As anticipated, we find that the primer extension block is absent in strains lacking either one or both ORFs comprising $A B P 140$ (Fig. 2A) and is restored in the deletion strains by introduction of a $C E N$ vector bearing wild-type $A B P 140$, but not by the empty vector (Fig. 2A).

To determine if other tRNA ${ }^{\mathrm{Thr}}$ and $\mathrm{tRNA}^{\mathrm{Ser}}$ species are also substrates for the presumed $\mathrm{m}^{3} \mathrm{C}$ modification directed by $A B P 140$, we used a similar primer extension assay. Both

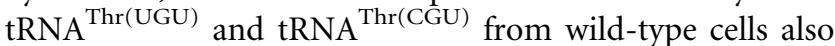
have the primer extension block expected of $\mathrm{m}^{3} \mathrm{C}$ modification at residue 32 (Fig. $2 \mathrm{~B}$, lanes e, h), but this primer

FIGURE 1. Identification of the gene responsible for $\mathrm{m}^{3} \mathrm{C}$ modification of yeast tRNA ${ }^{\operatorname{Thr}(\mathrm{IGU})}$. (A) Schematic of tRNA ${ }^{\operatorname{Thr}(\mathrm{IGU})}$ and primer used for assay of $\mathrm{m}^{3} \mathrm{C}_{32}$. Modifications found on $\mathrm{tRNA}^{\mathrm{Thr}(\mathrm{IGU})}$ are indicated (Weissenbach et al. 1977). The oligonucleotide used for primer extension by reverse transcriptase anneals to residues 55-35. Primer extension of $\mathrm{tRNA}^{\mathrm{Thr}(\mathrm{IGU})}$ species that contain $\mathrm{m}^{3} \mathrm{C}_{32}$ will terminate at residue 33 , whereas species lacking $\mathrm{m}^{3} \mathrm{C}_{32}$ will terminate at residue 27 before $\mathrm{m}^{2,2} \mathrm{G}_{26} \cdot \mathrm{m}^{2} \mathrm{G}$ indicates N2-dimethylguanosine; $D$, dihydrouridine; $\mathrm{m}^{2,2} \mathrm{G}, \mathrm{N}_{2}, \mathrm{~N}_{2}$-dimethylguanosine; I, inosine; $\mathrm{t}^{6} \mathrm{~A}$, N6-threonylcarbamoyladenosine; $\Psi$, pseudouridine; $\mathrm{m}^{5} \mathrm{C}$, 5-methylcytidine; T, ribothymidine; and $\mathrm{m}^{1} \mathrm{~A}, 1$-methyladenosine. (B) Validation of primer extension assay with AlkB-treated tRNA ${ }^{\text {Thr(IGU) }}$ tRNA $^{\text {Thr(IGU) }}$ purified from wild-type yeast cells was treated with the bacterial demethylating enzyme AlkB, and the resultant product was analyzed by the primer extension assay, as described in Materials and Methods. B indicates bulk RNA; P, purified tRNA; FL, full-length; $a, 2 \mu \mathrm{g}$ untreated bulk RNA; $b, c$, untreated tRNA ${ }^{\operatorname{Thr}(\mathrm{IGU})}(0.02 \mu \mathrm{g}$ and $0.2 \mu \mathrm{g}) ; d, e$, AlkB-treated tRNA ${ }^{\operatorname{Thr}(\mathrm{IGU})}(0.02 \mu \mathrm{g}$ and $0.2 \mu \mathrm{g})$; and $f$, no input RNA. (C) An abp140- $\Delta$ strain lacks the $\mathrm{m}^{3} \mathrm{C}$ primer extension block. Bulk RNA from a set of candidate deletion strains was screened by primer extension. RNA from the $a b p 140-\Delta$ strain lacking ORF YOR239W (lane 15) lacks the $\mathrm{m}^{3} \mathrm{C}$ primer extension block and has a block corresponding to $\mathrm{m}^{2,2} \mathrm{G}_{26}$. WT indicates RNA from wild-type control strain; AlkB, AlkB treated tRNA ${ }^{\text {Thr(IGU); }}$ and -, no RNA.

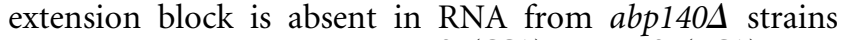
(lanes d, g). Similarly tRNA ${ }^{\text {Ser(CGA) }}$ tRNA $^{\text {Ser(UGA), and }}$ tRNA $^{\text {Ser(GCU) }}$ each have the primer extension block expected from $\mathrm{m}^{3} \mathrm{C}$ modification of the tRNA in wild-type cells, but the primer extension block is not observed in abp140- $\Delta$ cells (Fig. 2C).

To confirm the interpretation of our primer extension results that the primer extension block at residue 33 is due to $\mathrm{m}^{3} \mathrm{C}$ modification at residue 32 , we directly measured $\mathrm{m}^{3} \mathrm{C}$ levels in $\mathrm{tRNA}^{\mathrm{Thr}(\mathrm{IGU})}$. We purified tRNA ${ }^{\mathrm{Thr}(\mathrm{IGU})}$ from log phase cultures of the wild-type and deletion strains lacking either YOR239W or YOR240W, digested the RNA to nucleosides, and analyzed the nucleoside content by reverse-phase HPLC chromatography, as described in the Materials and Methods. We find that tRNA ${ }^{\text {Thr(IGU) }}$ from wild-type cells has approximately the expected levels of all nucleosides, including $0.92 \mathrm{~mol}$ of $\mathrm{m}^{3} \mathrm{C}$, whereas tRNA ${ }^{\mathrm{Th}(\mathrm{IGU})}$ from strains lacking either YOR239W or YOR240W has no detectable $\mathrm{m}^{3} \mathrm{C}$ but has otherwise similar levels of other nucleosides (Fig. 2D). These observations demonstrate directly that $A B P 140$ is required for the $\mathrm{m}^{3} \mathrm{C}$ modification

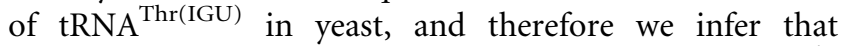
$A B P 140$ is required for $\mathrm{m}^{3} \mathrm{C}_{32}$ formation for all six $\mathrm{tRNA}^{\mathrm{Thr}}$ and $\mathrm{tRNA}^{\text {Ser }}$ species for which $\mathrm{m}^{3} \mathrm{C}$ is documented.

Based on these results, and the results below, we refer to the gene $A B P 140$ by the name TRM140, in keeping with nomenclature for other tRNA methyltransferases.

\section{Trm140p (Abp140p) is sufficient for $m^{3} \mathrm{C}$ modification of $t R N A^{\text {Thr(IGU) }}$ in vitro}

To determine if Trm140p (Abp140p) is required for $\mathrm{m}^{3} \mathrm{C}$ modification of $\mathrm{tRNA}^{\mathrm{Thr}(\mathrm{IGU})}$ in vitro, we prepared crude extracts from the wild-type and trm140- $\Delta$ (abp140- $\Delta$ ) strains and assayed their $\mathrm{m}^{3} \mathrm{C}$ methyltransferase activity with $S$-adenosylmethionine (SAM), using tRNA ${ }^{\text {Thr(IGU) }}$ transcribed in vitro with $\left[\alpha-{ }^{32} \mathrm{P}\right]$ CTP. After incubation of the transcripts with extracts, we digested the tRNA with $\mathrm{P} 1$ nuclease to generate $5^{\prime}-\left[{ }^{32} \mathrm{P}\right]$-labeled CMP and modified CMP residues, and resolved the products by thin-layer chromatography (TLC). We find that crude extracts from wild-type yeast cells have $\mathrm{m}^{3} \mathrm{C}$ methyltransferase activity (Fig. 3A, lanes a-d), since a modified CMP product is detected after resolution of the nucleotide reaction products on a PEI-cellulose TLC plate. This product co-migrates with an authentic labeled $\mathrm{m}^{3} \mathrm{C}$ spot, made by reaction of $\left[\alpha-{ }^{32} \mathrm{P}\right]$ CTP-labeled transcript with DMS, followed by $\mathrm{P} 1$ nuclease treatment, which is known to generate $5^{\prime}-\left[{ }^{32} \mathrm{P}\right] \mathrm{m}^{3} \mathrm{C}\left(\mathrm{p}^{\star} \mathrm{m}^{3} \mathrm{C}\right)$ (Heyman et al. 1994) This $\mathrm{p}^{\star} \mathrm{m}^{3} \mathrm{C}$ product is not detected in an extract from the trm140- $\Delta$ (abp140- $\Delta$ ) strain, even after overexposure of the TLC plate (Fig. 3A, lanes e-h), demonstrating that $\mathrm{m}^{3} \mathrm{C}$ methyltransferase activity in extracts requires Trm140p (Abp140p). Moreover, extracts prepared from cells overexpressing fulllength Trm140p with a nucleotide deleted to correct the 


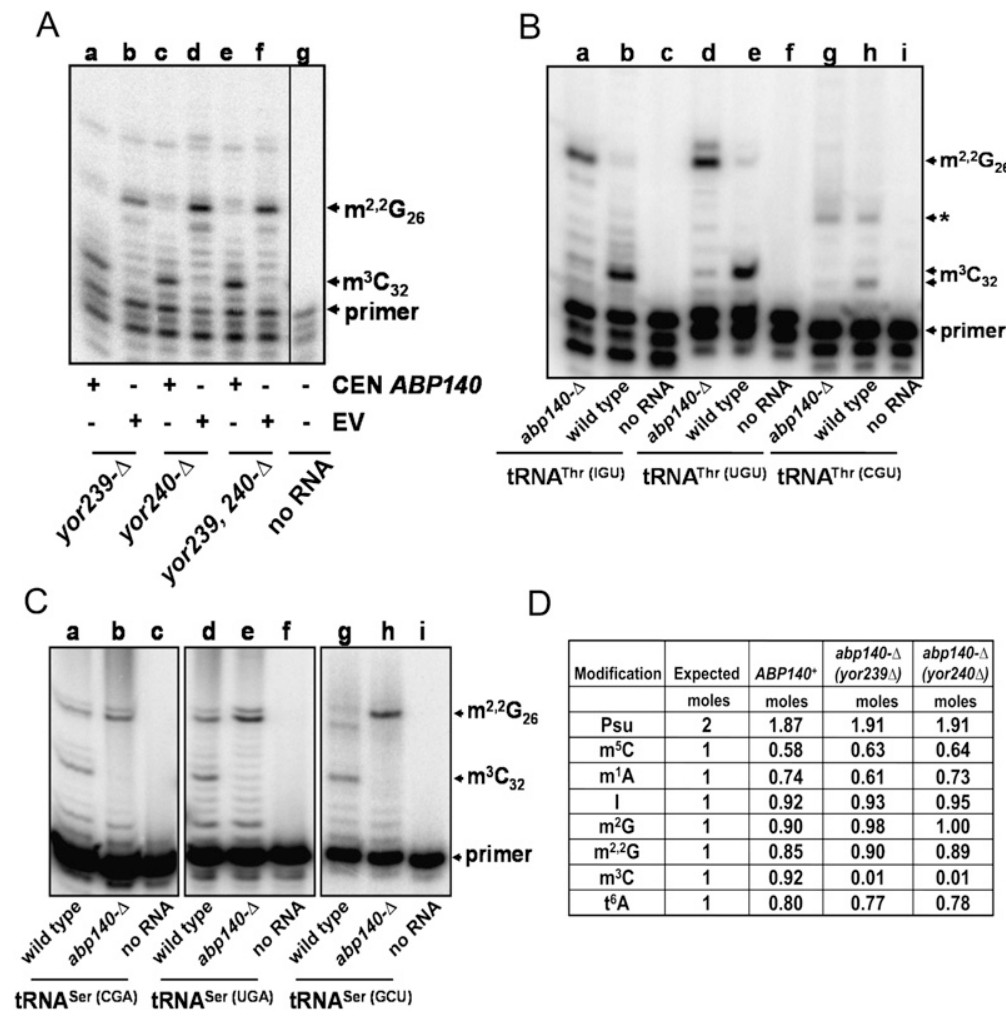

FIGURE 2. $A B P 140$ is required for $\mathrm{m}^{3} \mathrm{C}$ modification of $\mathrm{tRNA}^{\mathrm{Thr}}$ and $\mathrm{tRNA}{ }^{\mathrm{Ser}}$. (A) Lack of the $\mathrm{m}^{3} \mathrm{C}$ primer extension block is due to lack of ABP140. ORFs YOR239W and/or YOR240W were deleted by transformation of a wild-type strain (BY4741), and $2 \mu \mathrm{g}$ RNA from these strains was assayed for the $\mathrm{m}^{3} \mathrm{C}$ primer extension block after transformation with a CEN $A B P 140$ plasmid (lanes $a, c, e$ ), or with an empty vector (lanes $b, d, f$ ), as indicated. (Lane $g$ ) No RNA. Note that the $\mathrm{m}^{3} \mathrm{C}$ and $\mathrm{m}^{2,2} \mathrm{G}$ arrows point to the residue immediately preceding the modified residue that causes the primer extension block. (B) $A B P 140$ is required for $\mathrm{m}^{3} \mathrm{C}$ modification of other tRNA ${ }^{\text {Thr }}$ species. Bulk RNA $(2 \mu \mathrm{g})$ from a wild-type strain (lanes $\left.b, e, h\right)$ and an $a b p 140-\Delta$ strain $(a, d, g)$ was assayed by primer extension using $5^{\prime}$-labeled primers designed against tRNA ${ }^{\operatorname{Thr}(\mathrm{IGU})}(a-c), \operatorname{tRNA}^{\operatorname{Thr}(\mathrm{UGU})}(d-f)$, and tRNA ${ }^{\operatorname{Thr}(\mathrm{CGU})}(g-i)$. (Lanes $\left.c, f, i\right)$ no RNA controls; ${ }^{*}$, unexplained primer extension stop or pause in tRNA ${ }^{\mathrm{Thr}(\mathrm{CGU})}$. (C) ABP140 is required for $\mathrm{m}^{3} \mathrm{C}$ modification of $\mathrm{tRNA}^{\mathrm{Ser}(\mathrm{CGA})}, \mathrm{tRNA}^{\mathrm{Ser}(\mathrm{UGA})}$ and $\mathrm{tRNA}^{\mathrm{Ser}(\mathrm{GCU})}$. Bulk RNA $(2 \mu \mathrm{g})$ from a wild-type strain (lanes $a, d)$ and an $a b p 140-\Delta$ strain $(b, e)$ was assayed by primer extension using $5^{\prime}$-labeled primers designed against $\operatorname{tRNA}^{\operatorname{Ser}(\mathrm{CGA})}(a-c), \operatorname{tRNA}^{\operatorname{Ser}(\mathrm{UGA})}(d-f)$, and tRNA ${ }^{\operatorname{Ser}(\mathrm{GCU})}(g-i)$. (D) HPLC analysis of tRNA ${ }^{\mathrm{Thr}(\mathrm{IGU})}$ purified from an abpl40- $\Delta$ (trm140- $\Delta$ ) strain. RNA $^{\text {Thr(IGU) }}$ prepared from wild-type and abp140- $\Delta$ strains was digested to nucleosides and chromatographed on an HPLC column, as described in Materials and Methods.

need for a programed frameshift yielded about ninefold more $\mathrm{m}^{3} \mathrm{C}$ methyltransferase activity, based on the titration (Fig. 3A, lanes $\mathrm{i}-\mathrm{l}$ ), demonstrating that Trm140p is the limiting component of methyltransferase activity in extracts. Furthermore, the $\mathrm{m}^{3} \mathrm{C}$ methyltransferase activity is specific for its tRNA substrate, since no $\mathrm{p}^{*} \mathrm{~m}^{3} \mathrm{C}$ spot is detected after assay of $\left[\alpha-{ }^{32} \mathrm{P}\right]$ CTP-labeled tRNA ${ }^{\text {Phe }}$ transcript with either wild-type extracts or extracts from cells overexpressing Trm140p (Fig. 3A, lanes m, o), although $\mathrm{tRNA}^{\text {Phe }}$ has a $\mathrm{C}_{32}$ residue and although the tRNA $^{\text {Phe }}$ is clearly able to be modified by another modification activity that is present in the extracts.

To determine if Trm140p is sufficient for $\mathrm{m}^{3} \mathrm{C}$ methyltransferase activity, we expressed the gene with a C-terminal affinity tag in yeast or an N-terminal affinity tag in Escherichia coli and assayed activity after affinity purification (see Materials and Methods). To maximize production of the fulllength protein, we first deleted a nucleotide at the junction between ORF YOR239W and ORF YOR240W to encode the full-length fusion protein (labeled ff in the figures to indicate frame-fixed), but surprisingly, immunoblot analysis using antibody against the C-terminal tag shows that the expression of the framefixed Trm140p in yeast is very similar to that in a parallel construct with the programed frameshift (Supplemental Fig. S1). We find that purified Trm140ff protein (Supplemental Fig. S2A) exhibits readily detectable $\mathrm{m}^{3} \mathrm{C}$ methyltransferase activity in vitro (Fig. 3B, lanes a, b), and activity of the protein is very similar whether derived from a frame-fixed construct or the native construct (Supplemental Fig. S3, cf. lanes a-d and e-h), whereas the mock purification control from yeast with an empty vector has no detectable activity (Supplemental Fig. S3, lanes $\mathrm{i}-\mathrm{m})$. Activity is more prominent at 0 or $0.1 \mathrm{mM} \mathrm{MgCl}_{2}$ and is significantly reduced at $1 \mathrm{mM} \mathrm{MgCl} 2$ and at $10 \mathrm{mM} \mathrm{MgCl} 2$ (Supplemental Fig. S3). As is true in yeast crude extracts, Trm140p purified from yeast is specific, since activity is not detected with

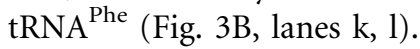

Both $\mathrm{m}^{3} \mathrm{C}$ methyltransferase activity and specificity are maintained after expression in E. coli, which does not normally have the modification or the activity. The frame-fixed $\operatorname{Trm} 140 \mathrm{p}$ purified after expression in E. coli (Supplemental Fig. S2B) has readily detectable $\mathrm{m}^{3} \mathrm{C}$ methyltransferase activity on tRNA ${ }^{\text {Thr }}$ (Fig. 3B, lanes $\mathrm{d}, \mathrm{e}$ ), but not on tRNA ${ }^{\text {Phe }}$ (lanes $\mathrm{n}, \mathrm{o}$ ), whereas no activity is detected in the mock purification from the corresponding E. coli vector control strain (lanes h, i). This finding demonstrates clearly that $\operatorname{Trm} 140 \mathrm{p}$ alone is sufficient for $\mathrm{m}^{3} \mathrm{C}$ methyltransferase activity and for tRNA specificity in the absence of other yeast proteins, although we have not yet quantitatively compared levels of activity from the protein produced in yeast and E. coli.

\section{Trm140p modifies tRNA ${ }^{\text {Thr(IGU) }}$ at position 32}

Two lines of evidence suggest that $\operatorname{Trm} 140 \mathrm{p}$ catalyzes $\mathrm{m}^{3} \mathrm{C}$ modification at $\mathrm{C}_{32}$ of tRNA ${ }^{\mathrm{Thr}(\mathrm{IGU})}$, rather than at another 
A

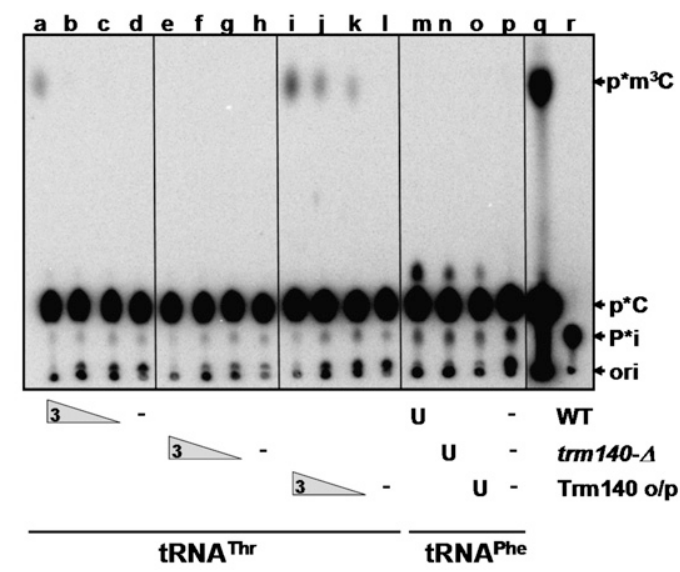

B

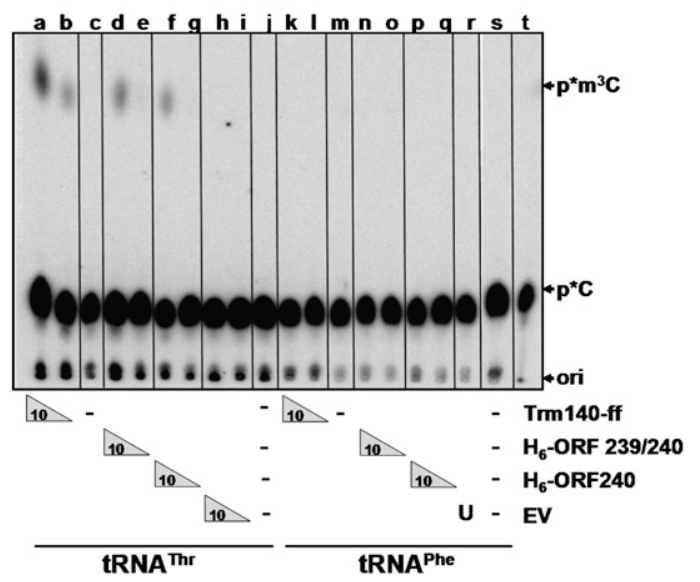

FIGURE 3. Trm140p (Abp140p) is sufficient for $\mathrm{m}^{3} \mathrm{C}$ methyltransferase activity. (A) Trm140p is the limiting component for detection of $\mathrm{m}^{3} \mathrm{C}$ methyltransferase activity in yeast extracts. $\mathrm{RRNA}^{\mathrm{Thr}(\mathrm{IGU})}$ transcribed in vitro with $\left[\alpha^{-32} \mathrm{P}\right]$ CTP was incubated in methyltransferase buffer containing serial threefold dilutions of extract from wild-type cells (lanes $a-c$ ), from trm140- $\Delta$ cells (lanes $e-g$ ), or from wild-type cells overexpressing frame-fixed Trm140p (Trm140-ff) in which the reading frames of ORFs YOR239W and YOR240W were deliberately fused (lanes $i-k$ ) for $2 \mathrm{~h}$ at $30^{\circ} \mathrm{C}$; then RNA was digested with P1 nuclease; and products were analyzed by chromatography on a PEI-cellulose developed in $0.25 \mathrm{M}$ lithium chloride, as described in Materials and Methods. $(m-o)$ Methyltransferase activity assayed with $\left[\alpha-{ }^{32} \mathrm{P}\right]$ CTP-transcribed tRNA ${ }^{\text {Phe }}$ with the highest concentration of extracts from wild-type cells $(m)$, trm140- $\Delta$ cells $(n)$, or wild-type cells overexpressing Trm140p $(o)$. (Lane $q$ ) $\mathrm{p}^{\star} \mathrm{m}^{3} \mathrm{C}$ control, generated by DMS-treatment of an $\left[\alpha^{-}{ }^{32} \mathrm{P}\right]$ CTP-labeled tRNA ${ }^{\text {Thr(IGU) }}$ transcript; (lane $r$ ) $\mathrm{P}^{\star_{i}}$ control. (B) Trm $140 \mathrm{p}$ expressed and purified from yeast or from E. coli has $\mathrm{m}^{3} \mathrm{C}$ methyltransferase activity. Methyltransferase activity was examined as described in $A$, with $\left[\alpha-{ }^{32} \mathrm{P}\right]$ CTP-transcribed tRNA ${ }^{\text {Thr(IGU) }}$, using preparations of frame-fixed Trm140p expressed and purified from yeast (lanes $\left.a, b\right)$, frame-fixed Trm140p expressed and purified from E. coli $(d, e)$, ORF YOR240W (the C-terminal SAM domain) expressed and purified from $E$. coli $(f, g)$, or with equivalent volumes of a parallel mock purification from $E$. coli cells containing an empty vector $(h, i)$. $c, j$, no protein; $k-s$, assay of methyltransferase using $\left[\alpha_{-}{ }^{32} \mathrm{P}\right]$ CTP-transcribed tRNA ${ }^{\text {Phe }} ; t$, DMS control.

position. First, formation of $\mathrm{m}^{3} \mathrm{C}$ requires the presence of the $\mathrm{C}_{32}$ residue of $\mathrm{TRNA}^{\mathrm{Thr}(\mathrm{IGU})}$. Thus, whereas $\operatorname{Trm} 140 \mathrm{p}$ readily catalyzes formation of $\mathrm{m}^{3} \mathrm{C}$ on a wild-type transcript of tRNA ${ }^{\operatorname{Thr}(\mathrm{IGU})}$, Trm140p does not have detectable activity on a tRNA ${ }^{\text {Thr(IGU) }}$ transcript with a $\mathrm{C}_{32} \mathrm{~A}$ mutation (Fig. 4A, cf. lanes $\mathrm{a}, \mathrm{b}$ ). This result strongly suggests that $\mathrm{C}_{32}$ is the target for methylation, although it is possible that the $\mathrm{C}_{32} \mathrm{~A}$ mutation instead alters recognition of the site of modification. Second, primer extension of in vitro modified $\mathrm{tRNA}^{\mathrm{Thr}(\mathrm{IGU})}$ demonstrates that the modification occurs at residue $\mathrm{C}_{32}$. To this end, we demonstrated that Trm140 activity was not saturated at concentrations of tRNA up to $800 \mathrm{nM}$, by competition experiments with labeled transcript and purified unlabeled tRNA ${ }^{\mathrm{Thr}(\mathrm{IGU})}$ (data not shown). In parallel, we treated $800 \mathrm{nM}$ tRNA ${ }^{\mathrm{Thr}(\mathrm{IGU})}$ from a trm140- $\Delta$ strain with the same amount of Trm140p (or with buffer) in the absence of labeled transcript. The treated products were then subjected to primer extension with the probe for $\mathrm{tRNA}^{\mathrm{Thr}(\mathrm{IGU})}$. We find that $\mathrm{RRNA}^{\mathrm{Thr}(\mathrm{IGU})}$ treated with the $T r m 140 p$ protein generated the $\mathrm{m}^{3} \mathrm{C}$ primer extension block at residue 33 (Fig. 4B, lane b), while tRNA $^{\text {Thr(IGU) }}$ treated only with buffer did not have the $\mathrm{m}^{3} \mathrm{C}$ primer-extension block (lane c). This result demonstrates that Trm140p modifies $\mathrm{C}_{32}$ of tRNA ${ }^{\mathrm{Thr}(\mathrm{IGU})}$. Furthermore, since Trm $140 \mathrm{p}$ modifies only $\leq 1$ mol of cytidine nucleotide per mole of $\mathrm{tRNA}^{\mathrm{Th}(\mathrm{IGU})}$, its specificity is limited to residue $\mathrm{C}_{32}$.

\section{ORF YOR239W is not required for the} methyltransferase activity of Trm140p

Since Trm 140p is synthesized by a programed frameshift to fuse ORFs YOR239W and YOR240W, it seems plausible that both ORFs are required for activity. However, prior experiments suggest that YOR239W encodes the protein moiety that interacts with actin (Gao and Bretscher 2008; Riedl et al. 2008), and evolutionary analysis of Abp140p demonstrates that this ORF is poorly conserved, whereas YOR240W, which encodes the methyltransferase domain, is widely conserved among eukaryotes (Asakura et al. 1998; Katz et al. 2003; Farabaugh et al. 2006a). Since $\mathrm{m}^{3} \mathrm{C}$ is also widely conserved among eukaryotes, this analysis suggests that $\mathrm{m}^{3} \mathrm{C}$ modification activity might be encoded solely by YOR240W, although it is also possible that the conserved programed frameshift that fuses the methyltransferase domain and the actin binding domain is catalytically or biologically important within $S$. cerevisiae and related organisms (Farabaugh et al. 2006a).

To address the link between the two domains of Trm140p, we evaluated the $\mathrm{m}^{3} \mathrm{C}$ methyltransferase activity of the ORF YOR $240 \mathrm{~W}$ protein in vitro and in vivo. We cloned ORF YOR240W (comprising residues 277-628) with an N-terminal ATG start codon into an E. coli expression vector, expressed and purified the protein (Supplemental Fig. S2), and then assayed activity. We find that purified His6-ORF240 has efficient $\mathrm{m}^{3} \mathrm{C}$ methyltransferase activity 
A

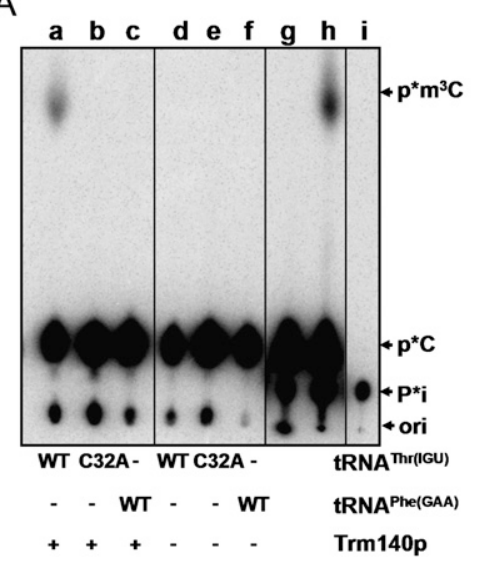

B

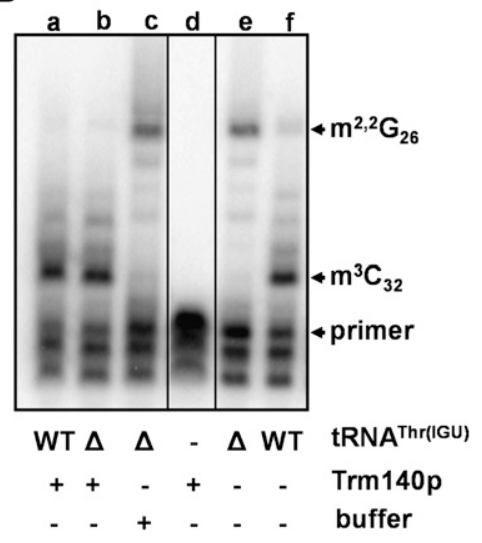

FIGURE 4. Trm140p modifies tRNA ${ }^{\text {Thr(IGU) }}$ at position 32. (A) Trm140p does not methylate a $\mathrm{C}_{32} \mathrm{~A}$ variant of $\mathrm{tRNA}{ }^{\mathrm{Thr}(\mathrm{IGU})}$. Trm140-ff protein purified from yeast $(0.13 \mu \mathrm{g} / \mu \mathrm{L})$ was assayed for $\mathrm{m}^{3} \mathrm{C}$ methyltransferase activity with $\left[\alpha-{ }^{32} \mathrm{P}\right]$ CTP-transcribed tRNA ${ }^{\operatorname{Thr}(\mathrm{GU})}(a)$, tRNA $^{\text {Thr(IGU) }} \mathrm{C}_{32} \mathrm{~A}$ variant $(b)$, or tRNA ${ }^{\text {Phe }}(c)$ for $24 \mathrm{~h}$ at $30^{\circ} \mathrm{C}$ and analyzed as described in Figure 3A. (Lanes $d-f$ ) tRNAs treated with buffer controls; (lanes $g, h$ ) untreated $(g)$ or DMS-

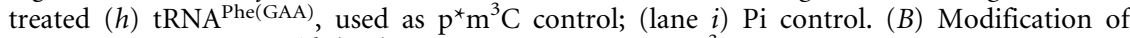
unlabeled purified tRNA ${ }^{\operatorname{Th}(\mathrm{IGU})}$ by Trm140p leads to an $\mathrm{m}^{3} \mathrm{C}_{32}$ primer extension block; $0.8 \mu \mathrm{g}$ tRNA $^{\text {Thr(IGU) }}$ purified from wild-type cells (lane $a$ ) or trm140- $\Delta$ strains (lanes $b, c$ ) was incubated for $24 \mathrm{~h}$ at $30^{\circ} \mathrm{C}$ in methyltransferase assay buffer with $0.13 \mu \mathrm{g} / \mu \mathrm{L}$ Trm140-ff protein purified from yeast (lanes $a, b$ ) or with buffer control (lane $c$ ), and the location of the $\mathrm{m}^{3} \mathrm{C}$ modification was analyzed by primer extension, as described in Figure 2. (Lanes $e, f$ ) primer extension of $0.8 \mu \mathrm{g}$ untreated tRNA $^{\operatorname{Thr}(\mathrm{IGU})}$ from trm140- $\Delta(e)$ and wild-type $(f)$ strains; (lane $d$ ) no RNA.

(Fig. 3B, lanes $\mathrm{f}, \mathrm{g}$ ), and that this activity is specific for tRNA $^{\text {Thr }}$ (lanes $\mathrm{p}, \mathrm{q}$ ). Thus, the SAM domain encoded by ORF YOR240W (Katz et al. 2003) is sufficient for the $\mathrm{m}^{3} \mathrm{C}$ methyltransferase activity in vitro, and the $\mathrm{N}$-terminal domain comprising ORF YOR239W is dispensable for both activity and specificity in vitro.

To determine if ORF YOR240W is sufficient for function in vivo, we deleted the N-terminal domain of TRM140 comprising ORF YOR239W from amino acids 12-276 and expressed TRM140- $\Delta 12-276$ in a $C E N$ plasmid. The resulting plasmid (CEN ORF TRM140- $\Delta 12-276)$ was introduced into a trm140$\Delta$ strain, and the $\mathrm{m}^{3} \mathrm{C}$ modification status of $\mathrm{tRNA}^{\mathrm{Thr}(\mathrm{IGU})}$ was analyzed by primer extension assay of the RNA. We find that the primer extension block diagnostic of $\mathrm{m}^{3} \mathrm{C}$ modification is observed when either the CEN TRM140 plasmid or the CEN ORF TRM140- $\Delta$ 12-276 plasmid is present (Fig. 5, lanes a, b), but no primer extension product is observed when the empty vector is expressed (lane c). These results demonstrate in vivo that the $\mathrm{m}^{3} \mathrm{C}$ methyltransferase activity of Trm140p on

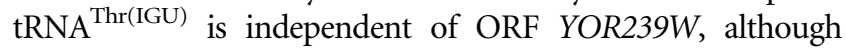
Trm140- $\Delta 12-276$ protein might still bind actin, since the N-terminal 17 amino acids of Trm140p (Abp140p) have been ascribed to this function (Riedl et al. 2008).

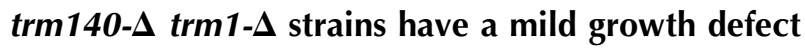 in the presence of cycloheximide}

Surprisingly, we find that trm140- $\Delta$ strains have no obvious growth defects under a variety of standard growth conditions. Thus, when assayed by standard serial dilution spotting experiments, we were unable to detect any growth defect on rich media (YP) or minimal synthetic media $(S)$, with either glucose (D) or glycerol (G) as carbon source, using a temperature range from $18^{\circ} \mathrm{C}-38^{\circ} \mathrm{C}$. In addition, the trm140- $\Delta$ strain is not sensitive to drugs such as cycloheximide, paramomycin, puromycin, and hygromycin (data not shown). The lack of obvious phenotype of a trm140- $\Delta$ strain is somewhat surprising because of the location of the $\mathrm{m}^{3} \mathrm{C}$ modification in the anticodon loop at residue 32 (see also Discussion). However, we find that a trm140- $\Delta$ trm1- $\Delta$ strain is mildly sensitive to low concentrations of cycloheximide $(0.25-0.3 \mu \mathrm{g} / \mathrm{mL})$ on rich (YPD) media (Fig. 6A) and that this sensitivity is complemented by reintroduction of a CEN TRM140 or a CEN TRM1 plasmid, but not by an empty vector control (Fig. 6B). This mild phenotype in the presence of cycloheximide suggests that lack of the $\mathrm{m}^{3} \mathrm{C}$ modification does impair translation, albeit mildly.

\section{DISCUSSION}

We have provided evidence that the $S$. cerevisiae gene ABP140 (now called TRM140) is necessary and sufficient for $\mathrm{m}^{3} \mathrm{C}$ modification at $\mathrm{C}_{32}$ of known tRNAs with this

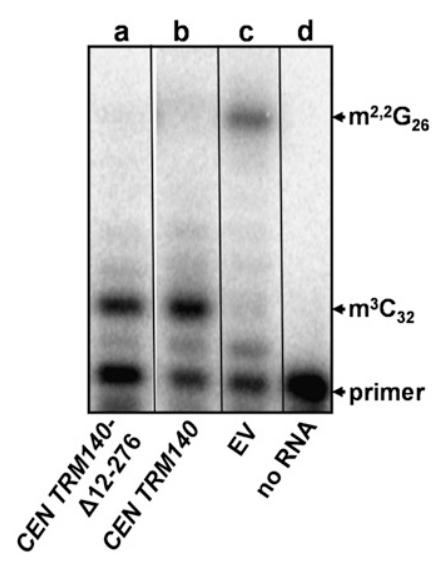

FIGURE 5. ORF YOR239W is not required for $\mathrm{m}^{3} \mathrm{C}$ methyltransferase activity in vivo. A trm140- $\Delta$ strain was transformed with CEN plasmids containing TRM140- $\Delta 12-276$ (lane $a$ ), TRM140 (lane $b$ ), or an empty vector (lane $c$ ), and bulk RNA $(2 \mu \mathrm{g})$ prepared from these strains was subjected to primer extension as described in Figure 2. (Lane $d$ ) No RNA. 
A

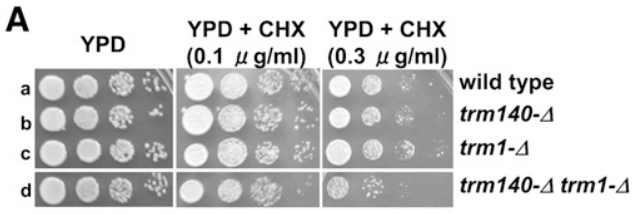

B

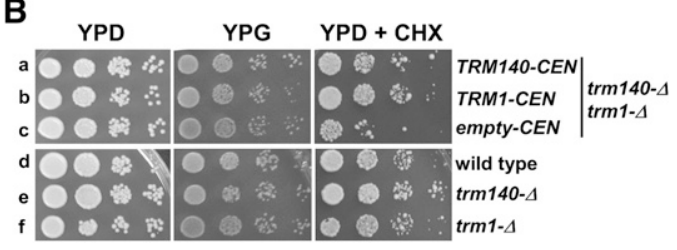

FIGURE 6. A trm140- $\Delta$ trm1 $\Delta$ mutant is sensitive to cycloheximide. (A) Enhanced cycloheximide sensitivity is observed in a trm140- $\Delta$ trm1- $\Delta$ strain. Wild-type (BY4741), abp140- $\Delta$ (ySD179), trm1- $\Delta$ (yLN005), and abp140- $\Delta$ trm1- $\Delta$ (ySD576) strains were grown at $30^{\circ} \mathrm{C}$ overnight, and $0.3 \mathrm{OD}$ cells were serially diluted by 10 -fold, spotted on rich (YPD) medium containing either $0,0.1$, or $0.3 \mu \mathrm{g} / \mathrm{mL}$ cycloheximide, and incubated at $30^{\circ} \mathrm{C}$ for $2 \mathrm{~d}$ (without cycloheximide) or $3 \mathrm{~d}$ (with cycloheximide). (B) Cycloheximide growth inhibition of a trm140- $\Delta$ trm1 $\Delta$ mutant is rescued by expression of TRM140 or TRM1. trm140- $\Delta$ trm1- $\Delta$ cells (ySD576) were transformed with a LEU2 CEN plasmid containing TRM140 (pSD158) or TRM1 (pMG67A) or with the control empty CEN LEU2 vector (AVA581), and transformants were grown overnight at $30^{\circ} \mathrm{C}$ in SD-Leu medium and spotted on YPD, YPG (glycerol) or YPD containing $0.25 \mu \mathrm{g} / \mathrm{mL}$ cycloheximide. Control wild-type (BY4741), trm140- $\Delta$ (ySD179), and trm1- $\Delta$ (yLN005) strains were transformed with the same empty vector and tested in parallel. Plates were incubated at $30^{\circ} \mathrm{C}$ for $2-3 \mathrm{~d}$.

modification. TRM140 is required for $\mathrm{m}^{3} \mathrm{C}$ modification, since the primer extension block normally imposed by $\mathrm{m}^{3} \mathrm{C}$ is absent in trm140- $\Delta$ mutants in all six tRNA species known to have this modification and since direct examination of nucleosides shows that purified tRNA ${ }^{\operatorname{Thr}(\mathrm{IGU})}$ from a trm140- $\Delta$ strain specifically lacks $\mathrm{m}^{3} \mathrm{C}$ that is normally found when the tRNA is purified from wild-type cells. We have also shown directly that Trm140p has $\mathrm{m}^{3} \mathrm{C}$ methyltransferase activity on tRNA ${ }^{\operatorname{Thr}(\mathrm{IGU})}$ by an assay of protein purified after expression in yeast or E. coli. Since this activity is specific for tRNA ${ }^{\text {Thr }}$ compared with tRNA ${ }^{\text {Phe }}$ and occurs specifically at residue 32 , we conclude that Trm140p is sufficient for $\mathrm{m}^{3} \mathrm{C}$ methyltransferase activity, although we have not quantitatively compared the activities, or examined other substrates in vitro.

It is intriguing that $\operatorname{Trm} 140 \mathrm{p}$ is synthesized by a programed +1 frameshift in which ORF YOR239W is fused to ORF YOR240W (Asakura et al. 1998), resulting in the fusion of an actin binding domain with the methyltransferase. Farabaugh and colleagues have done an extensive evolutionary analysis of the TRM140 (ABP140) gene and its programed frameshift, and find that ORF YOR239W is poorly conserved, whereas ORF YOR240W encodes a highly conserved SAM-methyltransferase domain (Katz et al. 2003; Farabaugh et al. 2006b). Furthermore, they find that the frameshift has been evolutionarily conserved for 150 $\mathrm{Myr}$, since it is extensively found in the budding yeasts, but not in other fungi (Farabaugh et al. 2006b).
There is good evidence that both domains of this protein are functional in yeast but in apparently different biological processes. Although most of the $\mathrm{N}$-terminal ORF YOR239W is very poorly conserved, it is clearly implicated in binding to actin in S. cerevisiae, since Abp140p was originally identified as an F-actin binding protein that colocalized with cortical actin patches and cytoplasmic actin cables (Asakura et al. 1998), and since the N-terminal 17 amino acids are sufficient for this activity (Riedl et al. 2008). Furthermore, the N-terminal ORF has biological function, since overexpression of the fragment encoding residues 1-218 of YOR239W suppresses the lethality conferred by overexpression of a domain of the formin Bnilp (Gao and Bretscher 2008), which nucleates actin filament formation (Pruyne et al. 2002).

Our finding that the C-terminal ORF YOR240W is necessary and sufficient for $\mathrm{m}^{3} \mathrm{C}$ methyltransferase activity in vitro and in vivo is consistent with the high conservation of both the ORF and $\mathrm{m}^{3} \mathrm{C}$ in fungi, metazoans, and plants and the lack of conservation of either ORF YOR239W or the frameshift (Farabaugh et al. 2006b), and suggests that the homologous ORFs encode the $\mathrm{m}^{3} \mathrm{C}$-methyltransferase activity. Thus, it appears that Trm140 protein fortuitously combines two ORFs with unrelated function, much like PUS8/RIB2 encodes the pseudouridyase that modifies position 32 in cytoplasmic tRNAs, as well as the unrelated DRAP (2,5-diamino-6-ribitylamino-4(3H)-pyrimidinone $5^{\prime}$-phosphate) deaminase that acts in riboflavin biosynthesis (Behm-Ansmant et al. 2004), although it remains to be explicitly determined if actin binding is important in vivo for Trm140p function.

The finding that trm140- $\Delta$ mutants have no detectable growth phenotype under a variety of conditions is somewhat surprising, given the widespread conservation of the $\mathrm{m}^{3} \mathrm{C}_{32}$ modification, the documented importance of the anti-codon loop in translation, the known interaction of residue 32 with residue 38 to affect structure of the anticodon loop (Auffinger and Westhof 1999, 2001), and the altered ribosome binding and translational fidelity of variants in these residues (Olejniczak et al. 2005; Olejniczak and Uhlenbeck 2006; Ledoux et al. 2009). We note, however, that there are large differences in the severity of growth defects observed in strains with mutations that prevent modification of residues in the anti-codon loop. Thus, severe growth defects are associated with loss of $\mathrm{I}_{34}$, $\mathrm{m}^{1} \mathrm{G}_{37}$, and $\mathrm{t}^{6} \mathrm{~A}_{37}$ (Gerber and Keller 1999; Bjork et al. 2001; El Yacoubi et al. 2009); less severe but pronounced growth defects are associated with loss of $\mathrm{Cm}_{32}$ and $\mathrm{Nm}_{34}$, and $\Psi_{38}$ and $\Psi_{39}$ (Lecointe et al. 1998, 2002; Pintard et al. 2002); and milder but distinct translational differences are associated with loss of $\mathrm{mcm}^{5} \mathrm{~s}^{2} \mathrm{U}_{34}, \mathrm{yW}_{37}$, and $\mathrm{i}^{6} \mathrm{~A}_{37}$ (Esberg et al. 2006; Waas et al. 2007). The lack of observable phenotype of cells lacking $\mathrm{m}^{3} \mathrm{C}_{32}$ is similar to that observed in mutants lacking $\mathrm{I}_{37}$ (Gerber et al. 1998), or the pseudouridylase moiety of PUS8, which is responsible for 
$\Psi_{32}$ modification (Behm-Ansmant et al. 2004). Modification of residue 32 may itself confer only subtle effects on translation, based on the lack of obvious phenotype of trm140- $\Delta$ mutants and of pus 8 alleles that specifically affect pseudouridylation, although the pronounced growth defect of trm7- $\Delta$ mutants might be partly due to its modification of residue 32 as well as residue 34 (Pintard et al. 2002).

Indeed, our evidence suggests that $\mathrm{m}^{3} \mathrm{C}$ modification has a distinct, albeit subtle translation effect, since a trm140- $\Delta$ trm1- $\Delta$ strain is mildly sensitive to low concentrations of cycloheximide, and this sensitivity is complemented by introduction of either a CEN TRM140 or a CEN TRM1 plasmid. Since the growth defect is observed in the presence of cycloheximide, which is known to affect the translocation step of translation (McKeehan and Hardesty 1969; SchneiderPoetsch et al. 2010) and requires a strain lacking both $\mathrm{m}^{3} \mathrm{C}_{32}$ and $\mathrm{m}^{2,2} \mathrm{G}_{26}$ (Ellis et al. 1986), it is highly likely that growth is affected due to impaired function of one or more tRNA species during translation. Since these two modifications occur in different regions of the tRNA, one simple interpretation of this result is that the modifications each partially impair function of one or more particular tRNAs in different ways and that the combined result is poor translation by those tRNAs. Alternatively, it is possible that both modifications alter the same property of the target tRNA by each impairing translocation or another step in translation, much like the Hirsh suppressor mutation in the D-stem affects translation fidelity in the anti-codon (Hirsh 1971).

It is tempting to speculate that the programed +1 frameshift has a biological function or is part of a regulatory loop, much as the +1 frameshift required for synthesis of the $S$. cerevisiae Oaz1 is triggered by high concentrations of polyamines in the cell, which then leads to inhibition of ornithine decarboxylase and lower polyamine levels (Palanimurugan et al. 2004), or as the bacterial release factor 2 (RF2) terminates its own synthesis at high concentrations of RF2 but permits +1 frameshifting otherwise (Craigen and Caskey 1986). Although the persistence of the +1 frameshift in TRM140 for 150 Myr suggests that the frameshift might constitute an important regulatory loop, the fact that the +1 frameshift appears to have been lost within the budding yeast clade by Saccharomyces castellii suggests that if the putative regulatory loop is important in budding yeast species, it is not crucial under evolutionary conditions (Farabaugh et al. 2006b). We note that the region just upstream of the frameshift in TRM140 has an unusual number of threonine codons and serine codons that require decoding by tRNAs with $\mathrm{m}^{3} \mathrm{C}$, but we do not yet know their significance.

\section{MATERIALS AND METHODS}

\section{Yeast strains}

Strains and oligomers used to construct strains are listed in Supplemental Tables S2 and S3. Strains used for genetic tests and/or analysis of tRNA were derivatives of strain BY4741 (Open Biosystems), and strains used for analysis of biochemical activity were derived from BCY123 (Macbeth et al. 2005), obtained from M.R. Macbeth. The TRM140 (ABP140) gene was deleted in strains BY4741 or BCY123 by PCR amplification of the $b l e^{R}$ cassette of pUG66 (Gueldener et al. 2002), using primers containing sequences directly $5^{\prime}$ and $3^{\prime}$ of TRM140 (ABP140 - 39+ Phleo and ABP140 + 38 + Phleo), followed by re-amplification with primers ABP140_UP75+Phleo and ABP140_DN75+Phleo, transformation, and selection on YPD media containing $8 \mu \mathrm{g} / \mathrm{mL}$ bleocin. The trm140- $\Delta$ trm1- $\Delta$ strain ySD576 was constructed by PCR amplification of the trm1- $\Delta$ :kanMX cassette from the corresponding knockout strain (Open Biosystems), using primers TRM1-300 and TRM1 + 366, followed by transformation into ySD179, and selection on YPD containing $300 \mu \mathrm{g} / \mathrm{mL}$ geneticin. Similar approaches were used for construction of other deletion strains, and all deletion strains were confirmed by PCR analysis using flanking chromosomal primers.

\section{Plasmids}

Plasmids and oligomers used to construct plasmids are listed in Supplemental Tables S4 and S5. CEN plasmids were made by ligation independent cloning (LIC) of appropriate DNA fragments into vectors AVA579 (CEN URA3) or AVA581 (CEN LEU2), which are derived from conventional $C E N$ vectors by incorporation of the LIC site of BG1861 (Alexandrov et al. 2004).

For expression in yeast and affinity purification, TRM140 was cloned by LIC into vector BG2663 ( $2 \mu$ URA3 $\mathrm{P}_{G A L}$-ORF-tag), which is similar to BG2483 (Malkowski et al. 2007), and results in fusion of the ORF to a complex tag containing a $3 \mathrm{C}$ site, followed by an HA epitope, His6, and the ZZ domain of protein A. This plasmid, pSD142 ( $2 \mu$ URA3 $\mathrm{P}_{G A L}$-TRM140-tag), was used to make pSD242 ( $2 \mu$ URA3 $\mathrm{P}_{G A L^{-}}$TRM140-frame fixed-tag), in which the translational frame of ORF YOR140W is fused directly to ORF YOR239W, by deletion of nucleotide 829 of the $A B P 140$ (TRM140) coding sequence. This was accomplished using primers 5'ABP140-fix frame and 3'ABP140-fix frame and the Quikchange mutagenesis kit (Stratagene).

For expression in E. coli as a His6-3C-ORF, frame fixed TRM140 from pSD242 (or ORF YOR240W) was PCR amplified and cloned by LIC into expression vector AVA421 (Quartley et al. 2009).

\section{Growth and affinity purification of Trm140p from yeast}

For purification of Trm140p from yeast, yeast ORF expression plasmids pSD142 $\left(2 \mu\right.$ URA3 $\mathrm{P}_{G A L^{-}}$TRM140-tag $)$and pSD242 $(2 \mu$ URA3 $\mathrm{P}_{G A L^{-}}$TRM140-frame fixed-tag) were transformed into strain BCY123 (Macbeth et al. 2005). Transformants were grown as described (Quartley et al. 2009), except that cells were harvested $6 \mathrm{~h}$ after induction with $3 \times$ YP media containing $6 \%$ galactose, yielding 5 OD-L of cells.

Crude extracts were made by bead beating, and tagged protein was purified as described (Quartley et al. 2009) by binding to IgG Sepharose, elution of bound protein with GST-3C protease, removal of protease, and dialysis in buffer containing $20 \mathrm{mM}$ Tris-Cl (pH 7.5), $150 \mathrm{mM} \mathrm{NaCl}, 1 \mathrm{mM} \mathrm{DTT}, 1 \mathrm{mM} \mathrm{MgCl}_{2}$, and $50 \%$ glycerol, followed by storage at $-20^{\circ} \mathrm{C}$. 


\section{Growth and affinity purification of His6-Trm140p, His6-ORF YOR240w, and His6-AlkB from E. coli}

E. coli expression plasmids were transformed into pLys(S)BL21(DE3) cells, and transformants were grown in $25 \mathrm{~mL} \mathrm{LB}$ medium containing $200 \mu \mathrm{g} / \mathrm{mL}$ ampicillin, at $30^{\circ} \mathrm{C}$ overnight, diluted $1: 200$, grown to an $\mathrm{OD}$ of 0.6 at $30^{\circ} \mathrm{C}$, induced by addition of IPTG to $2 \mathrm{mM}$, and grown for $3 \mathrm{~h}$ at $30^{\circ} \mathrm{C}$. Cells from a $1 \mathrm{~L}$ growth were harvested and sonicated in $8 \mathrm{~mL}$ of buffer containing $50 \mathrm{mM}$ Tris ( $\mathrm{pH}$ 7.5), $100 \mathrm{mM}$ EDTA, $4 \mathrm{mM} \mathrm{MgCl}_{2}, 5 \mathrm{mM}$ DTT, $5 \%$ sucrose, $1 \mathrm{M} \mathrm{NaCl}$, and protease inhibitors, and tagged protein was purified from crude extracts by binding to Talon resin, and elution of bound protein with $250 \mathrm{mM}$ imidazole, followed by dialysis in buffer containing $20 \mathrm{mM}$ Tris- $\mathrm{Cl}$ (pH 7.5), $200 \mathrm{mM}$ $\mathrm{NaCl}, 1 \mathrm{mM}$ DTT, and $50 \%$ glycerol and storage at $-20^{\circ} \mathrm{C}$

\section{Isolation of bulk low-molecular-weight RNA}

Yeast strains were grown in YPD or minimal media at $30^{\circ} \mathrm{C}$ to mid-log phase, cells were harvested in 300 OD pellets, and lowmolecular-weight RNA was isolated using hot phenol, as described previously (Jackman et al. 2003). For small-scale isolation of bulk low-molecular-weight RNA, yeast cells were grown in $5 \mathrm{~mL}$ liquid YPD or minimal media to an OD of 2.5-3.0, and rapid RNA preps were prepared as described (Schmitt et al. 1990).

\section{tRNA purification}

tRNA $^{\text {Thr(IGU) }}$ was purified from bulk low-molecular-weight yeast RNA using a 5' -biotinylated oligomer, 5' Bio tRNA ${ }^{\text {Thr }}$ (5' Bio-AAC CGAGAUCUCCACAUUAC- $3^{\prime}$; Integrated DNA Technologies) that is complementary to nucleotides $35-55$ of tRNA ${ }^{\text {Thr(IGU) }}$, essentially as described (Jackman et al. 2003), followed by desalting and concentration using Amicon MLtra-4 10,000 MWCO columns (Millipore).

\section{Primer extension assays}

Oligomers used for primer extension are shown in Supplemental Table S6; 30 pmol primers were labeled with $49 \mathrm{pmol}\left[\gamma_{-}{ }^{32} \mathrm{P}\right] \mathrm{ATP}$ (7000 Ci/mmol MP Biologicals) using T4 polynucleotide kinase (Roche), followed by removal of excess label using a Micro Biospin 6 chromatography column (Bio-Rad), gel purification, phenol extraction, and ethanol precipitation. Primer extension assays were done essentially as described (Jackman et al. 2003). In a $5 \mu \mathrm{L}$ reaction, $1-2 \mathrm{pmol}$ of $5^{\prime}$ end-labeled primers were annealed to $2 \mu \mathrm{g}$ of bulk RNA or $0.2 \mu \mathrm{g}$ purified tRNA by heating to $95^{\circ} \mathrm{C}$ for $5 \mathrm{~min}$ and cooling at room temperature for 30-60 min. The annealed reaction was then extended using 0.8 U AMV reverse transcriptase (Promega) in a $10 \mu \mathrm{L}$ reaction containing $1 \times \mathrm{AMV}$ RT buffer and $0.11 \mathrm{mM}$ of each $\operatorname{dNTP}(\mathrm{A}, \mathrm{C}, \mathrm{G}$, and T) for $1 \mathrm{~h}$ at $37^{\circ} \mathrm{C}$. The extension reaction was stopped using RNA load dye ( $10 \mu \mathrm{L}$ formamide containing $0.1 \%$ bromophenol blue and $0.1 \%$ xylene cyanol) and quick frozen in dry ice. The frozen reactions were heated for $5 \mathrm{~min}$ to $95^{\circ} \mathrm{C}$, cooled on ice, and loaded on a polyacrylamide sequencing gel containing $4 \mathrm{M}$ urea. The gel was dried and exposed on a phosphoimager cassette.

\section{In vitro transcription}

Plasmids EMP1568 and EMP1577 (containing tRNA ${ }^{\text {Thr(IGU) and }}$ tRNA $^{\text {Phe }}$ under control of T7 polymerase) were digested with Bst
$\mathrm{N} 1$ for $3 \mathrm{~h}$ at $60^{\circ} \mathrm{C}$ and transcribed withT7 RNA polymerase in a $20 \mu \mathrm{L}$ reaction mixture containing $50 \mathrm{mM}$ Tris $(\mathrm{pH} 8), 1 \mathrm{mM}$ spermidine, $30 \mathrm{mM} \mathrm{MgCl}_{2}, 7.5 \mathrm{mM}$ DTT, $4 \mathrm{mM}$ ATP, $4 \mathrm{mM}$ GTP, $4 \mathrm{mM}$ UTP, and $0.1 \mathrm{mM}$ CTP, $0.1 \mathrm{mg} / \mathrm{mL}$ DNA, and 50-100 $\mu \mathrm{Ci}\left[\alpha^{32} \mathrm{P}\right] \mathrm{CTP}(3000 \mathrm{Ci} / \mathrm{mmol}$ from Perkin Elmer) for $1.5 \mathrm{~h}$ at $37^{\circ} \mathrm{C}$, followed by $10 \%$ PAGE, elution of RNA, and resuspension in $10 \mu \mathrm{L} \mathrm{TE}(\mathrm{pH} \mathrm{7.5)}$.

\section{$\mathbf{m}^{3} \mathrm{C}$ methyltransferase assay}

$\mathrm{m}^{3} \mathrm{C}$ methyltransferase activity was assayed in $20 \mu \mathrm{L}$ reaction mixtures containing $50 \mathrm{mM}$ Tris- $\mathrm{HCl}(\mathrm{pH} 8.0), 1 \mathrm{mM}$ dithiothreitol (DTT), $0.1 \mathrm{mM}$ ethylenediaminetetraacetic acid (EDTA), $1 \mathrm{mM}$ spermidine, $0.5 \mathrm{mM}$ SAM, 5000-10,000 cpm of the corresponding specifically labeled transcript, and a source of $\mathrm{m}^{3} \mathrm{C}$ methyltransferase activity (crude extract or purified protein). Reactions were incubated for $4 \mathrm{~h}$ at $30^{\circ} \mathrm{C}$ and then stopped by the addition of $90 \mu \mathrm{L}$ of $0.5 \mathrm{M}$ Tris- $\mathrm{HCl}(\mathrm{pH} 8.0$ ) containing $20 \mu \mathrm{g}$ carrier tRNA, followed by phenol extraction and ethanol precipitation of the RNA. RNA was resuspended in $5 \mu \mathrm{L}$ solution containing $30 \mathrm{mM}$ sodium acetate $(\mathrm{pH} 5.3), 0.2 \mathrm{mM} \mathrm{ZnCl}_{2}$, and $1 \mu \mathrm{g} / \mu \mathrm{L}$ of $\mathrm{P} 1$ nuclease and incubated for $1 \mathrm{~h}$ at $50^{\circ} \mathrm{C}$, and digestion products were applied to PEI-cellulose TLC plates (EM Science) and resolved in buffer containing saturated $0.25 \mathrm{M}$ lithium chloride.

\section{HPLC analysis of nucleosides}

Purified tRNA ${ }^{\text {Thr }}(1.25 \mu \mathrm{g})$ isolated from yeast was treated with $0.5 \mu \mathrm{g}$ of $\mathrm{P} 1$ nuclease in buffer containing $30 \mathrm{mM}$ sodium acetate ( $\mathrm{pH} 5.2$ ) and $0.2 \mathrm{mM} \mathrm{ZnCl}_{2}$ for $16 \mathrm{~h}$ at $37^{\circ} \mathrm{C}$ and then with $8 \mathrm{U}$ of calf intestinal alkaline phosphatase (Roche) in $1 \times$ alkaline phosphatase reaction buffer for $1 \mathrm{~h}$ at $37^{\circ} \mathrm{C}$. The resulting nucleosides were resolved by HPLC as described (Jackman et al. 2003).

\section{AlkB demethylation}

Purified tRNA $^{\text {Thr }}(1.25 \mu \mathrm{g})$ isolated from yeast was treated with His6-AlkB from E. coli B (purified from a clone obtained from B. Sedgwick [Dinglay et al. 2000] using TALON Resin, as described above) in buffer containing $50 \mathrm{mM}$ Hepes $\mathrm{KOH}(\mathrm{pH} 8), 75 \mu \mathrm{M}$ ferrous ammonium sulfate, $1 \mathrm{mM} \alpha$-ketoglutarate, $2 \mathrm{mM}$ ascorbate, and $50 \mu \mathrm{g} / \mathrm{mL}$ BSA for $30 \mathrm{~min}$ at $37^{\circ} \mathrm{C}$ and then stopped as described (Trewick et al. 2002).

\section{DMS methylation reaction to generate $5^{\prime}\left[{ }^{32} \mathrm{P}\right] \mathrm{m}^{3} \mathrm{CMP}$}

$150,000 \mathrm{cpm}\left[\alpha^{32} \mathrm{P}\right] \mathrm{CTP}$ labeled transcript was treated with DMS ( $1: 10$ dilution in $100 \%$ ethanol) in $20 \mu$ l reaction mixture containing $50 \mathrm{mM}$ HEPES ( $\mathrm{pH} 7.5$ ) and $1 \mathrm{mM}$ EDTA for 15 $\min$ at $70^{\circ} \mathrm{C}$ in a fume hood. The reaction was stopped with 300 $\mathrm{mM}$ sodium acetate $(\mathrm{pH}$ 6) and ethanol precipitated, and the pellet was resuspended and digested with $0.5 \mu \mathrm{g} / \mu \mathrm{L}$ P1 nuclease for $1 \mathrm{~h}$ at $50^{\circ} \mathrm{C}$.

\section{SUPPLEMENTAL MATERIAL}

Supplemental material is available for this article. 


\section{ACKNOWLEDGMENTS}

We thank Juan Alfonzo and Kirk Gaston for valuable discussions on assays, Elizabeth Grayhack and Melanie Preston for invaluable insight and discussions throughout this work, M.R. Macbeth (Carnegie Mellon University) for providing the BCY123 strain, B. Sedgwick (Cancer Research UK London Research Institute) for providing the E. coli AlkB clone, and Kimberly Dean, Josh Dewe, Michael Guy, Dan Letzring, and Joseph Whipple for comments on the manuscript. This research was supported by NIH Grant GM52347 to E.M.P.

Received January 31, 2011; accepted March 9, 2011.

\section{REFERENCES}

Aas PA, Otterlei M, Falnes PO, Vagbo CB, Skorpen F, Akbari M, Sundheim O, Bjoras M, Slupphaug G, Seeberg E, et al. 2003. Human and bacterial oxidative demethylases repair alkylation damage in both RNA and DNA. Nature 421: 859-863.

Alexandrov A, Vignali M, LaCount DJ, Quartley E, de Vries C, De Rosa D, Babulski J, Mitchell SF, Schoenfeld LW, Fields S, et al. 2004. A facile method for high-throughput co-expression of protein pairs. Mol Cell Proteomics 3: 934-938.

Asakura T, Sasaki T, Nagano F, Satoh A, Obaishi H, Nishioka H, Imamura H, Hotta K, Tanaka K, Nakanishi $\mathrm{H}$, et al. 1998. Isolation and characterization of a novel actin filament-binding protein from Saccharomyces cerevisiae. Oncogene 16: 121-130.

Auffinger P, Westhof E. 1999. Singly and bifurcated hydrogen-bonded base-pairs in tRNA anticodon hairpins and ribozymes. J Mol Biol 292: $467-483$.

Auffinger P, Westhof E. 2001. An extended structural signature for the tRNA anticodon loop. RNA 7: 334-341.

Behm-Ansmant I, Grosjean H, Massenet S, Motorin Y, Branlant C. 2004. Pseudouridylation at position 32 of mitochondrial and cytoplasmic tRNAs requires two distinct enzymes in Saccharomyces cerevisiae. J Biol Chem 279: 52998-53006.

Bjork GR, Jacobsson K, Nilsson K, Johansson MJ, Bystrom AS, Persson OP. 2001. A primordial tRNA modification required for the evolution of life? EMBO J 20: 231-239.

Chernyakov I, Whipple JM, Kotelawala L, Grayhack EJ, Phizicky EM. 2008. Degradation of several hypomodified mature tRNA species in Saccharomyces cerevisiae is mediated by Met22 and the $5^{\prime}-3^{\prime}$ exonucleases Rat1 and Xrn1. Genes Dev 22: 1369-1380.

Craigen WJ, Caskey CT. 1986. Expression of peptide chain release factor 2 requires high-efficiency frameshift. Nature 322: 273-275.

Dinglay S, Trewick SC, Lindahl T, Sedgwick B. 2000. Defective processing of methylated single-stranded DNA by E. coli AlkB mutants. Genes Dev 14: 2097-2105.

Dunin-Horkawicz S, Czerwoniec A, Gajda MJ, Feder M, Grosjean H, Bujnicki JM. 2006. MODOMICS: a database of RNA modification pathways. Nucleic Acids Res 34: D145-D149.

Ellis SR, Morales MJ, Li JM, Hopper AK, Martin NC. 1986. Isolation and characterization of the TRM1 locus, a gene essential for the N2,N2dimethylguanosine modification of both mitochondrial and cytoplasmic tRNA in Saccharomyces cerevisiae. J Biol Chem 261: 9703-9709.

El Yacoubi B, Lyons B, Cruz Y, Reddy R, Nordin B, Agnelli F, Williamson JR, Schimmel P, Swairjo MA, de Crecy-Lagard V. 2009. The universal YrdC/Sua5 family is required for the formation of threonylcarbamoyladenosine in tRNA. Nucleic Acids Res 37: 2894-2909.

Esberg A, Huang B, Johansson MJ, Bystrom AS. 2006. Elevated levels of two tRNA species bypass the requirement for elongator complex in transcription and exocytosis. Mol Cell 24: 139-148.

Farabaugh AH, Sonawalla SB, Fava M, Pedrelli P, Papakostas GI, Schwartz F, Mischoulon D. 2006a. Differences in cognitive factors between "true drug" versus "placebo pattern" response to fluoxetine as defined by pattern analysis. Hum Psychopharmacol 21: 221-225.
Farabaugh PJ, Kramer E, Vallabhaneni H, Raman A. 2006b. Evolution of +1 programmed frameshifting signals and frameshift-regulating tRNAs in the order Saccharomycetales. J Mol Evol 63: 545-561.

Gao L, Bretscher A. 2008. Analysis of unregulated formin activity reveals how yeast can balance F-actin assembly between different microfilament-based organizations. Mol Biol Cell 19: 1474-1484.

Gerber AP, Keller W. 1999. An adenosine deaminase that generates inosine at the wobble position of tRNAs. Science 286: 1146-1149.

Gerber A, Grosjean H, Melcher T, Keller W. 1998. Tad1p, a yeast tRNA-specific adenosine deaminase, is related to the mammalian pre-mRNA editing enzymes ADAR1 and ADAR2. EMBO J 17: $4780-4789$.

Gueldener U, Heinisch J, Koehler GJ, Voss D, Hegemann JH. 2002. A second set of loxP marker cassettes for Cre-mediated multiple gene knockouts in budding yeast. Nucleic Acids Res 30: e23. doi: 10.1093/nar/30.6.e23.

Hall RH. 1963. Isolation of 3-methyluridine and 3-methylcytidine from solubleribonucleic acid. Biochem Biophys Res Commun 12: 361-364.

Heyman T, Agoutin B, Fix C, Dirheimer G, Keith G. 1994. Yeast serine isoacceptor tRNAs: variations of their content as a function of growth conditions and primary structure of the minor tRNA(Ser)GCU. FEBS Lett 347: 143-146.

Hirsh D. 1971. Tryptophan transfer RNA as the UGA suppressor. J Mol Biol 58: 439-458.

Jackman JE, Montange RK, Malik HS, Phizicky EM. 2003. Identification of the yeast gene encoding the tRNA m1G methyltransferase responsible for modification at position 9. RNA 9: 574-585.

Kadaba S, Krueger A, Trice T, Krecic AM, Hinnebusch AG, Anderson J. 2004. Nuclear surveillance and degradation of hypomodified initiator tRNAMet in S. cerevisiae. Genes Dev 18: 1227-1240.

Katz JE, Dlakic M, Clarke S. 2003. Automated identification of putative methyltransferases from genomic open reading frames. Mol Cell Proteomics 2: 525-540.

Lecointe F, Simos G, Sauer A, Hurt EC, Motorin Y, Grosjean H. 1998. Characterization of yeast protein Deg1 as pseudouridine synthase (Pus3) catalyzing the formation of psi 38 and psi 39 in tRNA anticodon loop. J Biol Chem 273: 1316-1323.

Lecointe F, Namy O, Hatin I, Simos G, Rousset JP, Grosjean H. 2002. Lack of pseudouridine 38/39 in the anticodon arm of yeast cytoplasmic tRNA decreases in vivo recoding efficiency. $J$ Biol Chem 277: 30445-30453.

Ledoux S, Olejniczak M, Uhlenbeck OC. 2009. A sequence element that tunes Escherichia coli tRNA(Ala)(GGC) to ensure accurate decoding. Nat Struct Mol Biol 16: 359-364.

Macbeth MR, Schubert HL, Vandemark AP, Lingam AT, Hill CP, Bass BL. 2005. Inositol hexakisphosphate is bound in the ADAR2 core and required for RNA editing. Science 309: 1534-1539.

Malkowski MG, Quartley E, Friedman AE, Babulski J, Kon Y, Wolfley J, Said M, Luft JR, Phizicky EM, DeTitta GT, et al. 2007. Blocking S-adenosylmethionine synthesis in yeast allows selenomethionine incorporation and multiwavelength anomalous dispersion phasing. Proc Natl Acad Sci 104: 6678-6683.

McKeehan W, Hardesty B. 1969. The mechanism of cycloheximide inhibition of protein synthesis in rabbit reticulocytes. Biochem Biophys Res Commun 36: 625-630.

Olejniczak M, Uhlenbeck OC. 2006. tRNA residues that have coevolved with their anticodon to ensure uniform and accurate codon recognition. Biochimie 88: 943-950.

Olejniczak M, Dale T, Fahlman RP, Uhlenbeck OC. 2005. Idiosyncratic tuning of tRNAs to achieve uniform ribosome binding. Nat Struct Mol Biol 12: 788-793.

Palanimurugan R, Scheel H, Hofmann K, Dohmen RJ. 2004. Polyamines regulate their synthesis by inducing expression and blocking degradation of ODC antizyme. EMBO J 23: 4857-4867.

Phizicky EM, Hopper AK. 2010. tRNA biology charges to the front. Genes Dev 24: 1832-1860.

Pintard L, Lecointe F, Bujnicki JM, Bonnerot C, Grosjean H, Lapeyre B. 2002. Trm7p catalyses the formation of two 2'-O-methylriboses in yeast tRNA anticodon loop. EMBO J 21: 1811-1820. 


\section{D'Silva et al.}

Pruyne D, Evangelista M, Yang C, Bi E, Zigmond S, Bretscher A, Boone C. 2002. Role of formins in actin assembly: nucleation and barbed-end association. Science 297: 612-615.

Quartley E, Alexandrov A, Mikucki M, Buckner FS, Hol WG, DeTitta GT, Phizicky EM, Grayhack EJ. 2009. Heterologous expression of L. major proteins in S. cerevisiae: a test of solubility, purity, and gene recoding. J Struct Funct Genomics 10: 233-247.

Riedl J, Crevenna AH, Kessenbrock K, Yu JH, Neukirchen D, Bista M, Bradke F, Jenne D, Holak TA, Werb Z, et al. 2008. Lifeact: a versatile marker to visualize F-actin. Nat Methods 5: 605607.

Schmitt ME, Brown TA, Trumpower BL. 1990. A rapid and simple method for preparation of RNA from Saccharomyces cerevisiae. Nucleic Acids Res 18: 3091-3092.
Schneider-Poetsch T, Ju J, Eyler DE, Dang Y, Bhat S, Merrick WC, Green R, Shen B, Liu JO. 2010. Inhibition of eukaryotic translation elongation by cycloheximide and lactimidomycin. Nat Chem Biol 6: 209-217.

Sprinzl M, Vassilenko KS. 2005. Compilation of tRNA sequences and sequences of tRNA genes. Nucleic Acids Res 33: D139-D140.

Trewick SC, Henshaw TF, Hausinger RP, Lindahl T, Sedgwick B. 2002. Oxidative demethylation by Escherichia coli AlkB directly reverts DNA base damage. Nature 419: 174-178.

Waas WF, Druzina Z, Hanan M, Schimmel P. 2007. Role of a tRNA base modification and its precursors in frameshifting in eukaryotes. J Biol Chem 282: 26026-26034.

Weissenbach J, Kiraly I, Dirheimer G. 1977. Primary structure of tRNA Thr la and b from brewer's yeast. Biochimie 59: 381-391. 

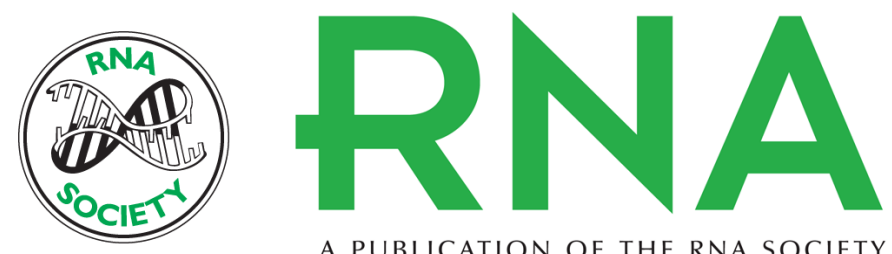

A PUBLICATION OF THE RNA SOCIETY

\title{
A domain of the actin binding protein Abp140 is the yeast methyltransferase responsible for 3-methylcytidine modification in the tRNA anti-codon loop
}

\author{
Sonia D'Silva, Steffen J. Haider and Eric M. Phizicky
}

RNA 2011 17: 1100-1110 originally published online April 25, 2011

Access the most recent version at doi:10.1261/rna.2652611

Supplemental Material

Related Content

References

\section{License}

Email Alerting Service
http://rnajournal.cshlp.org/content/suppl/2011/04/01/rna.2652611.DC1

Actin-binding protein ABP140 is a methyltransferase for 3-methylcytidine at position 32 of tRNAs in Saccharomyces cerevisiae Akiko Noma, Sanghyun Yi, Takayuki Katoh, et al. RNA June , 2011 17: 1111-1119

This article cites 46 articles, 22 of which can be accessed free at: http://rnajournal.cshlp.org/content/17/6/1100.full.html\#ref-list-1

Articles cited in:

http://rnajournal.cshlp.org/content/17/6/1100.full.html\#related-urls

Receive free email alerts when new articles cite this article - sign up in the box at the top right corner of the article or click here. 